Makale türü / Article type: Araştırma / Research

\title{
Kınalızade Ali Efendi ile Thomas Hobbes'un Yönetim Yaklaşımları Üzerine Bir inceleme ${ }^{1}$ $* * *$
}

\section{A Review on the Management Approaches of Kinalızade Ali Efendi and Thomas Hobbes}

\author{
Doç. Dr. Uğur Keskin \\ Anadolu Üniversitesi, İşletme Fakültesi, ugurkeskin@anadolu.edu.tr \\ Dr. Öğr. Üyesi İlker Usta \\ Anadolu Üniversitesi, Açıköğretim Fakültesi, ilkerusta26@gmail.com
}

\begin{abstract}
Özet
$\mathrm{Bu}$ çalışmada, Türk filozof Kınalızade Ali Efendi ile İngiliz filozof Thomas Hobbes'in yönetim yaklaşımları karşılaştırılmıştır. Birbirinin çağdaşı bu filozofların düşünsel dünyalarını, içinde yer almış bulundukları bağlamdan kopararak ele almak mümkün olamamaktadır. Kınalızade ve Hobbes, içinde yetiştikleri toplumun temel dinamiklerini, eserlerine ve bakış açılarına yansıtmışlardır. Söz konusu yansımalar, düşünsel düzlemdeki Doğu-Batı düalizminin karakteristiği çerçevesinde belirginleşmiştir. Alan yazında, Kınalızade ile Machiavelli karşılaştırması yapan çalışmalarla karşılaşabilmek mümkün olmasına karşın, Kınalızade ile Hobbes karşılaştırmasına yönelik çalışmalara ulaşmak aynı ölçüde mümkün olamamaktadır. İki filozof arasında ortaya çıkan ayrımlar öylesine belirgin derecelerde kendini göstermektedir ki, bu durum, yönetim yaklaşımları bakımından ortaya çıkan farklılaşmanın doğal karşılanması gerektiğine ilişkin değerlendirmeleri de beraberinde getirmektedir. $\mathrm{Bu}$ çalışmada yürütülen incelemeler sonucunda, teorik öngörü olarak filozoflar arasında var olduğuna kanaat getirilen düşünsel ayrışma temeline dayalı olarak, yönetim yaklaşımları bakımından da anlamlı farklılaşmaların ortaya çıkmakta olduğu belirlenmiştir.
\end{abstract}

Anahtar Kelimeler: Kınalızade Ali Efendi, Thomas Hobbes, Yönetim Yaklaşımları, Yönetici-Yönetilen İlişkileri

JEL Sınıflandırması: Z10, Z11, Z12, Z13.

\footnotetext{
${ }^{1}$ Bu makale, 02-05 Ekim 2017 tarihleri arasında Antalya'da düzenlenen Türk Dünyası Stratejik Araştırmalar Kongresi'nde Uğur Keskin ve İlker Usta tarafından sözlü sunumu yapılan "Kınalizade Ali Efendi ile Thomas Hobbes'un Yönetim Yaklaşımlarının Karşılaştırılması" başlıklı bildirinin genişletilerek farklılaştırılmış hâlidir.
} 


\begin{abstract}
In this study, the management approaches of the Turkish philosopher Kınalıade Ali Efendi and the British philosopher Thomas Hobbes were compared. It is not possible to tackle these contemporary of one another philosophers' intellectual worlds in the context of what they are involved in. Both Kinalizade and Hobbes reflected the basic dynamics of the society in which they grew up to their works and viewpoints. These reflections became evident in the characterization of East-West dualism in the intellectual plane. Although it is possible to encounter works that compare Kinalizade and Machiavelli in the literature, it is not possible to reach the studies for comparison of Kinalizade and Hobbes equally. The distinctions between the two philosophers manifest themselves at such a pronounced level that it can bring about the need to naturally meet the differentiation in terms of management approaches. As a result of the studies carried out within the scope of this study, it has been determined that based on the intellectual diversity which is believed to exist among the philosophers as theoretical predictions, they also show a meaningful differentiation in terms of management approaches.
\end{abstract}

Keywords: Kinalıade Ali Efendi, Thomas Hobbes, Management Approaches, Manager-Managed Relationships

JEL Classification: Z10, Z11, Z12, Z13.

\title{
GíRIŞ
}

Kınalızade (1511-1572), ahlaki konular başta olmak üzere birçok alanda eserler yazmıştır. Kınalızade, ilmi çevreyle iç içe olan bir aileden gelmiştir. Çeşitli medreselerde ilmi faaliyetler yürütmüştür. Daha sonra ise Şam, Kahire, Halep, Bursa ve Edirne'de de kadılık yaptıktan sonra 1570’te İstanbul kadılığına atanmıştır. Bir yıl sonra Anadolu Kazaskerliğine atanmış ve Sultan II. Selim'in mahiyetinde Edirne'de görev yapmıştır (Öztürk, 1991, s. 60-61). Kınalızâde, genel olarak ahlak eksenli eserler yazmış olmasına karşın, yazdığı eserlerde yönetimsel konulara da değinmiştir. Çeşitli konuları ele aldığı eserleri şunlardır (Yavuz, 2015, s. 12):

\author{
Ahlâk-ı Alâi \\ Tecrid Haşiyesi \\ Mevakıf Haşiyesi \\ Durer ve Gurer Haşiyesi \\ Kalemiye Risalesi \\ Seyfiyye Risalesi \\ Divan
}

Tabakat-ı Hanefiye 


\section{Bedrettin Guzzi ile Tefsir Tartışmaları}

Ulemadan Şah Efendi İle Vakfa Ait Konuşmalar

Beyzaviye Haşiyesi

Keşsefa Haşiyesi

Kınalızâde; Nasıreddin Tusi ve Celaleddin Devvani'nin Aristocu, Gazali'nin tasavvufçu olan ahlakından tercümeler ve telifler yaparak Türkçe ahlak eserleri yazmıştır (Ülken, 2009, s. 139). Kınalızade, başyapıtı olan Ahlâk-ı Alâi adlı eserinde genel olarak devlet ahlakından bahsettiği için ve devlet ahlakını da, aile ahlakına dayandırdığı için bu eser günümüz Türkçesine genellikle "Devlet ve Aile Ahlakı" olarak çevrilmektedir.

Kınalızade; birey, aile ve devlet ahlakı hususlarını ağırlıklı olarak ele almıştır. Bu yönüyle Kınalızade, Sokrates'in ifade etmiş olduğu yönetimin evrensel yönlerini ele alarak kapsamlı bir şekilde açıklaması bakımından önemli eserler yazmıştır. Kınalızade, anlatımlarında Sokrates, Platon, Aristoteles, Sadi Şirazi gibi düşünürlerin eserlerinden de örnekler aktararak yönetimsel öğüt ve tavsiyelerde bulunmuştur (Keskin, 2012a, s. 170).

İnsanların, kendi güvenliğini ve kendi hazzını arıyor olmasından dolayı yarışmacılık ve başkalarına güvensizlik bulundurdukları kanaatini taşıyan Hobbes, onların ortak bir erk altında yaşamaya başladıkları zamana dek sürekli olarak birbirleri ile savaş durumunda oldukları fikrini savunmuştur (Copelston, 1998, s.40). Hobbes, materyalist bir epistemoloji bir insan doğası anlayışına dayanarak kaleme aldığı yönetimsel hususlara ilişkin eserlerinde, güvenlik ve özgürlük arasındaki gerilimi ele almış ve çözümü, egemene mutlak itaatte bulmuştur. En temel eserleri şunlardır (Hobbes, 2014, s. i):

\section{Elements of Law, Natural and Politics}

De Cive

Leviathan

De Corpore

De Homine 


\section{A Dialogue Between Philosopher and aStudent of the Common Laws of England}

Behemoth

Yukarıdaki anlatımlarda, Kınalızade ile Hobbes hakkında genel bilgiler aktarılmıştır. Aşağıdaki anlatımlardaki müteakip başlıklarda ise Kınalızade ve Hobbes'un eserinde değindiği konular içinde yönetimsel anlamda birbirleri ile karşılaştırma yapma konusunda anlamlı veriler sunan başlıca hususlar ele alınarak okuyucunun dikkatine sunulmuştur.

\section{1. ÇALIŞMANIN AMACI, ÖNEMI VE METODOLOJISİ}

Filozof olmaları nedeniyle Kınalızade ve Hobbes, eserlerinde tek bir konu özelinde odaklanmamış, farklı çalışma alanlarına konu olabilecek hususlar üzerinde durmuşlardır. Bu çalışma, birbirleriyle çağdaş olan iki filozofun yönetim anlayışlarını karşılaştırmak amacıyla gerçekleştirilmiştir. Günümüzde yönetim birçok alt alana ayrılmakla birlikte en belirgin çerçeve olarak kamu ve özel yönetim şeklinde farklılaşmakta burada da siyaset/kamu yönetimi ile işletme yönetimi şeklinde ikili bir ayrım olarak ortaya çıkmaktadır. Bu çalışmada kamu-özel veya siyaset/kamu-işletme ayrımı olmaksızın, Kınalızade ile Hobbes'un yönetimsel hususlara yönelik bakış açıları ortaya konularak karşılaştırılmıştır. Literatürde özellikle son yıllarda Kınalızade'nin eserlerini inceleyen çalışmaların arttığı göze çarpsa da Kınalızade, çoğunlukla İtalyan düşünür Machiavelli ile benzer veya ayrılan yönleri bakımından ele alınmaktadır. Türkçe literatürde Machiavelli ile ilgili kaynakların çok daha fazla olmasının, bu durumun ortaya çıkmasına kaynaklık etmesi olası görünmektedir. Söz konusu durum, yani Kınalızade ile Hobbes arasında (yönetim yaklaşımlarından bağımsız olarak) karşılaştırmalı çalışmaların yapılmamış olması, bu makaleden sonra yapılacak araştırmalara keşifsel katkı sağlaması bakımından okumakta olduğunuz çalışmanın önemini ifade etmektedir.

Keşifsel araştırmalar, hakkında yeterince bilgiye sahip olunmayan ya da belirli bir zaman diliminde incelenmemiş olguları ortaya çıkarma amacı taşımaktadır. Sosyal bilimlerdeki keşifsel çalışmalar, daha çok tarihsel yönü bulunan araştırmalar şeklinde ortaya çıkmaktadır (Saruhan ve Özdemirci, 2005, s.114). Bu makale, karşılaştırmalar içermesine karşın, keşifsel yönü daha ağır basan bir çalışmadır. Zira, çalışmanın amacı ve önemine yönelik 
anlatımlarda da ifade edildiği üzere bu çalışma, üzerinde yeterince durulmamış bir inceleme alanını konu edinerek bu alanda katkı sağlamayı amaçlayan bir özelliğe sahip bulunmaktadır.

\section{KINALIZADE İLE HOBBES'UN YÖNETIM YAKLAŞIMLARININ KARŞILAŞTIRILMASI}

Aralarında varoluşsal farklılıklar bulunan iki ayrı özne veya olgu, zaten "farklı" oldukları için söz konusu iki unsur arasında fark bulunduğunu ileri sürmenin totolojik (ilave bilgi vermeyen, kendini tekrar eden) bir önerme olduğu yönündeki mantıksal ket vurmalardan bağımsız olarak bu çalışma yürütülmüş ve her iki filozof tarafindan yazılan ve hâlihazırda Türkçe'ye çevirileri yapılmış bulunan bütün birincil kaynak eserleri incelemeye konu edilmiştir.

Kınalızade ile diğer pek çok düşünür kıyaslanmış, bunlar içinde özellikle Machiavelli ile olan karşılaştırmalara sıç̧a başvurulmuştur. Machiavelli ile başladığı kabul edilen modern anlayış, yönetime konu olan hususları, değer boyutundan bağımsız olarak ele alan bir yaklaşımı öne çıkarmış (Davutoğlu, 2010, s. 15) ve başta Hobbes olmak üzere ardılı olan birçok Batılı düşünürü etkilemiştir. Bu etkilenmenin temel bir göstergesi olması bakımından ve Doğu ile Batı nasihatnamecilerini, Machiavelli ile Kınalızade özelinde karşılaştırması bakımından aşağıdaki aktarım, anlamlı bir bakış açısı sunmaktadır (Fukuyama ve diğ., 2003, s. 339):

Hobbes'un İngiliz iç savaşında ve bunalım döneminde ürettiği fikirler, sıradan bir İngiliz'in güvenlik anlayışından doğan fikirlerdir. Rousseu'nun Fransız Devrimi'nin hemen öncesinde ürettiği fikirler, o dönemin Fransızlarını ilgilendiren problematikle ilgilidir. Hegel'in tarih anlayışı ise her şeyi kuşatmaya çalışır; her şeyi Almanya ekseninde kuşatmaya çalışır. Aynen Kınalızade'nin her şeyi Osmanlı'da birleştirmeye çalışması gibi... Kınalızade'nin kitabında eski İran geleneği vardır, hemen hemen her sayfada Platon ile Aristo görülür, İslam düşüncesinin her rengi görülür. Kınalızade'yi buna sevk eden şey, kuşatıcı olma çabasıdır. Çünkü kitabını sunduğu kişi, üç kıtayı, çok sayıda topluluğu bir arada tutmaya çalışan bir sultandır.

Kınalızade ile diğer düşünürler arasında yapılan ve yukarıda örnekleri aktarılan çalışmalara benzer türden birçok araştırma ve inceleme yapılmıştır (Özdemir, 2012; Yavuz, 2015) fakat Kınalızade ile Hobbes arasında karşılaştırma özelinde yapan çalışmalarla aynı sıklıkla karşılaşabilmek 
mümkün olmamaktadır. Dolayısıyla bu çalışmanın, söz konusu eksikliği belirli ölçülerde giderebilme amacına yönelik olarak yapılandırılmış olması, çalışmanın özgün değeri olarak belirginlik kazanmaktadır.

\subsection{Yönetici-Yönetilen İlişsilerine Dair Görüşleri}

Kınalızade, yönetici ile onun altında çalışanlar arasındaki ilişikler konusundaki görüşünü şu sözlerle ifade etmişsir: "Düşünmek gerektir ki, insanın yaratılışı hizmet eden ve hizmet edilen (amir-memur) arasında müşterektir. $\mathrm{Bu}$ nedenle insaf ve adaleti elden bırakmamak lazımdır" (Kınalızade, 2010, s. 79). "Bu dünyada kimseyi incitme. Öyle bir yere gideceksin ki orada efendi ile köle eşittir". Bu yaklaşımıyla Kınalızade, yönetici-yönetilen ilişkilerinde tek yanlı bağımlılık ilişkisinden ziyade, karşılıklı bağımlılık ilişkisini ön plana çıkarmıştır.

Kınalızade, yetişmiş devlet başkanını bilgili hekime, halkı ise bir bedene benzemektedir. Hekimin, beden hastalıklarının neler olduğunu bilmesi gerekmektedir. Devletin başlangıçta kurulması, bir grup bireyin anlaşarak, yardımlaşmalarıyla ve bir bedenin uzuvları gibi olmalarıyla mümkün olmaktadır. Zira her bir bireyin kendine özgü bir kuvvetli yönü bulunmaktadır. Bu kuvvetli yönler bir araya gelince kuvvet büyümektedir. Her bir grup birey, devletin unsurlarını teşkil etmektedir (Kınalızade, 2010, s. 169-170). Kınalizade, devleti oluşturan unsurlar olarak bireyler arasında din, dil veya etnik grup gibi ayrımların yapılmadığı ideal bir devlet yapısını izah etmiştir. Söz konusu ideal yapıya işlerlik kazandırması bakımından adaletin şartları ve devlet başkanlarının vasıfları olarak; herkese eşit muamele, herkesin hakkına ve istidadına (doğuştan gelen yeteneğine) göre korunması, iyilik ve yardımın da aynı ölçüler çerçevesinde yapılması gerektiğini ifade etmiştir (Keskin 2012b, s. 81).

Devletin başında yönetici olan hükümdarı bir "hekim" olarak tarif eden Kınalızade'ye göre hükümdar, memleketin sıhhat (sağlı) durumunu iyi bilmesi ve bu konuda itidalli (temkinli) olması gerekmektedir. Memleketin hastalığı ise itidalden (normal durumdan) anormal duruma, düzenlilikten kargaşalığa geçmiş olmasıdır. "Esas sıhhate ve gerçek düzene hangi tedbirle dönebilir?” sorusu, iktidar doktorluğunun ilmi yönünü ifade etmektedir. 
Bundan sonra bu bilgiyi uygulamaya geçirmeyi ise doğruluğun ölçüsü olarak tanımlamıştır (Kınalızade, 2010, s. 169).

Hekimlik mesleği, doğal bir gereklilik olarak bütünsel düşünmeyi öncelemektedir. Kınalızade'nin bu benzetmesinden yola çıkarak, yönetici konumundaki hükümdarın, devletin sıhhati (devletin bekası ve yürütme erkine dair yapılması gerekenler) bakımından bir hekim titizliğiyle hareket etmesi gerektiği anlaşılmaktadır. Kınalızade, hükümdarlara has temel bir nitelik olarak sahip bulunulması gereken söz konusu bütünsel yaklaşımı, organizmacı bir örnekle açıklamıştır. Kınalızade'ye göre "bedendeki organlardan birine hastalık gelecek olsa, hekim, tedavide o organın kendi durumuna bakmaz. Bilakis bedenin umumi durumunu dikkate alır”. Kınalızade, vermiş olduğu bu örnekle, parçaları tek tek düşünmek yerine bütünün, yani sistemin genel çıkarının ön planda tutulması gerektiğini ifade etmiştir. Bu düşünce, on dokuzuncu yüzyılda organizmacı düşünür Herbert Spencer tarafından daha kapsamlı hale getirilerek açıklanmıştır. Spencer'a göre, gerek bireyin kendi içinde gerekse örgütün birer parçası olan bireyler arasında, karşılıklı ilişki ve bağl1lık söz konusu olmaktadır ve bu şekliyle bireyler ile örgütler, canlı bir biyolojik organizma gibi davranmaktadırlar. Organizmacı yaklaşım, genellikle işbirliği boyutunu vurgulamış ve örgütlerin, ortak bir amaca yönelmiş tek tek parçalardan oluşan yekvücut bir organizma olarak kabul edilmesi gerektiği görüşünü ileri sürmüştür (Fukuyama, 2005, s.62). Spencer ve öncülü Kınalızade'nin bu yaklaşımları, modern yönetim anlayışlarına kaynaklık etmiş ve çağdaş yönetim sorunlarının anlaşılarak giderilmesinde kapsayıcı bir çatı sunan teorik izah olan "sistem yaklaşımı" kuramının düşünsel temelini teşkil etmiştir (Keskin ve Büyük, 2013, s.18).

Hobbes'un yönetim yaklaşımının esası, yerleşik bir otoriteye karşı gelmenin her zaman için yanlış olduğu görüşüne dayanmaktadır. Aklı başında insanlar, kendi yararlarını düşünerek, böylesi bir başkaldırmanın başarılı olamayacağı, bunun için de başkaldırıya teşebbüs edilemeyecek bir yönetimsel yapılanmanın (devlet de dahil bütün yönetimsel yapılanmalar) kurgulanmas1 gerekmektedir (Watkins, 2000, s. 54). Hobbes, bu konuda "uyum" kavramını daha çok ön plana çıkarmıştır. Hobbes'a göre uyum, devletin sağlıklı olduğuna, isyan/anarşi ise onun hastalığına işaret etmektedir. 
Devletin ölümü de iç savaş durumunda gerçekleşmektedir (Çıvgın ve Yardımcı, 2007, s. 94). Hobbes'a göre ise devlet, insan tarafindan yaratılmış yapay bir organizmadır; insana nazaran devasa boyutlara/yetkilere sahip olabilen bir organizma. Devlet organizmasının ruhu ise egemenliktir. Devletin bütün organlarına hayat veren, memurları harekete geçiren temel ilkeyi söz konusu mekanik anlamdaki bu ruhtan ibaret olarak görmektedir. Ödül ve ceza sistemleri ise devletin sağlıklı bir biçimde işleyebilmesi için gerekli olan sinirlerdir (Çıvgın ve Yardımcı, 2007, s. 94). Hobbes'un bakış açısına bakıldığında doğal yaşam formu gibi işleyen fakat özünde mekanik bir düzenin tarif edilmekte olduğu görülmektedir.

\subsection{Güç ve Hakimiyet İlişkilerine Bakışları}

Kınalızade, realist anlayıştan belirli ölçülerde farklılaşan bakış açısıyla, idealist ve normatif bir yaklaşım benimsemiştir. Aşağıya aktarılan anlatımlar, Kınalızade'nin bu konudaki genel yaklaşımını yansıtmaktadır: Nefsin, görüş ve iş anlaşmazlığında uyuşma yönünü seçip herkesle barışık ve iyilik üzere olması, saadetin temelidir. Kişi bunun sayesinde emniyet ve huzur içinde olur, mutlu bir hayat yaşar. Bir milletin fertleri arasında barış içinde olma fikri gelişmişse, aralarında sevgi ve kardeşlik bağları da kuvvetlenir... Dahili dostlukları kuvvetli olan fertler, doğru yolda birleşebilirler (Kınalızade, 2011, s. 22-23). Hobbes, insanların nefsani yönlerine sürekli vurgu yaparken Kınalızade, zaruretin miktarınca eyleme geçmeyi, hırs ve tamaha düşmemeyi, "kanaat" anlayışının bir gereği olarak ortaya koymuştur. Kınalızade (2011, s, 25); yetinmeyi, bilinçli bir rıza davranışına yönelmeyi geçici lezzetlere haddinden fazla dalmamayı vurgulamaktadır.

Kınalızade, hükümdarın (yöneticinin) ne tür yol ayrımlarıyla karşılaşabileceğini kendi bakış açısına göre izah etmiştir. O'na göre yönetim iki kısımdan oluşmaktadır: Birincisi fazilete dayalı yönetimdir ki tam ve olgun idare anlamına gelmektedir. İkincisi ise fazilete dayalı olmayan yönetim, bu da tegallübe (üstünlük zihniyetine) dayalı idaredir. Birinci idarede idarecinin amacı Allah'ın ahlakı ile ahlaklanmak, ikinci idarede idarecinin amacı ise nefsine uymaktır (Kınalızade, 2010, s. 151). 
Kınalızade'ye göre, himmet ve gayret sahibi olan devlet başkanına; hoş vakit ve rahat hayatın zevkleri ve işret (safahat), iktidarına mani olmamalıdır. Dünyevi hevesler, onu devlet ve vatan düşmanları ile savaşmaktan alıkoymamalıdır (Kınalızade, 2010, s. 155). Hükümdarlar; azim, sebat, kuvvet ve ihtiyata dayanmalıdır. Sağlam olmayan karar ve ihtiyatsızlıkta kararın devamı düşünülemez. İhtiyatsız karar ve bunda 1srar, lüzumsuz ve yersiz bir inat ve kuru bir kibirden ibaret kalır. Nice hükümdar bu inat ve direnmeyi sebat zannedip, hem kendini, hem de mahiyetini zor durumda bırakmıştır (Kınalızade, 2010, s. 161). Burada da görüldüğü üzere Kınalızade her ne kadar idealist bir çizgide yer alıyor olmasına karşın, devletin bekası konusunda yöneticilerin sahip olması gereken temel nitelikleri ya da ihtiyatlilık bakımından asgari müşterek olarak ifade edilebilecek hususları da ele almayı ihmal etmemiştir.

Hobbes, Machiavelli'nin temellendirdiği güç ve egemenlik merkezli yaklaşımı izlemiş ve rasyonel, basit ve gerçek olanı görebilme eksenli bir anlayışı benimsemiştir. Buna karşın Hobbes, tam anlamıyla yalnızca somut varlıklarla sınırlı bir gerçeklik öngörmemiş, aksine yukarıdaki paragrafta da ifade açıklandığı üzere, kutsal kitaptan aldığı ilhamla, ruhani bir başlık taşıyan Leviathan adlı başyapıtını kaleme almıştır (Arıboğan, 1998, s. 82). Kitab-1 Mukaddes'te Leviathan, diğer bütün hayvanlar üzerinde hâkimiyet kurmuş bir timsahtır. Onun hakimiyeti altında yaşamayı gururlarına yediremeyen bazı hayvanlar, timsahın elindeki otoriteyi almak istemiş fakat timsahın derisindeki keskin pullardan dolayı hiçbiri ona yaklaşamamış (Watkins, 2000, s. 54) dolayısıyla da otoritesini sarsamamıştır. Hobbes, yönetimsel yapılanmanın en genel çerçevesini teşkil eden devlet için bu benzetmeyi yaparak, "kadife eldiven içindeki demir yumruk" söylemini destekleyen totaliter anlayışı yüceltmiştir. Aklı başında olmanın yolu, Hobbes'a göre, realist olmaktan geçmektedir zira aklı başında realist insanlar, yıkıcı nitelikler taşıyan hırs ve gurura kapılmamaları gerektiğini öngörebilmektedirler.

Hobbes'un tarif etmiş olduğu ve hakimiyeti temsil eden varlık olan Leviathan, gerçeklikte çok bir ütopyayı betimlemektedir. Bu da Batı dünyasını çok uzun yıllar etkisi altına almış olan Thomas Moore'un (1478-1535) ütopyacı literatür geleneğinin bir uzantısını işaret etmektedir. Dolayısıyla, 
"Hobbes'un realizmi de bu etkilerle bezenmiş, biraz ütopik bir realizmdir". Hobbes da, tıpkı kendisinden önceki realistler gibi, insanın özü itibariyle aktif, saldırgan ve güç sahibi olma arzusu ile rekabet ederek çatışan hâkim mizaç sahibi varlıklar olduğuna inanmaktadır (Arıboğan, 1998, s. 83-84).

Hobbes, insanların, diğerleri karşısında hakimiyetçi ve rekabetçi bir yaradılışa sahip olduğunu ileri sürmüştür (Homo homini lupus: İnsan insanın kurdudur). Ortada birbiriyle çatışan çıkarlar olması nedeniyle de insanlar, diğerlerinin aleyhine olacak şekilde güçlerini artırma çabası içine girmektedirler. $\mathrm{Bu}$ ise kaçınılmaz bir şekilde düzensizliğe sürüklenme sonucunu ortaya çıkarmaktadır. Söz konusu düzensizliğin ortadan kaldırılabilmesi için ise yine kaçınılmaz bir şekilde mutlak itaat sağlayıcı bir otoritenin varlığı ile mümkün olabilmektedir. Her ne kadar Hobbes bunu açık bir dille ifade etmemiş olsa da bu görüşler, Hollandalı düşünür Hugo Grotius'a dayanmaktadır (Atayman, 2006, s. 43). Bir insanın arzu nesnesine ulaşma koşulu, güç sahibi olmasıdır. Güç isteği ise bütün geri kalan isteklerin kendisine indirgenebileceği bir istektir ve onun antropolojisinin temelini teşkil etmektedir (Zelyüt, 2010, s. 30).

\subsection{Bireylerin Varoluşsal Kaygılarına Dair Görüşleri}

Kınalızade, fazilet ve iyi huy olarak tanımladığı davranışlar olarak “cömertlik", "cesurluk" ve "yumuşaklık" vasıflarını ön plana çıkarmıştır. Rezalet ve çirkin huy olarak ise "korkaklık" ve "hafiflik" vasıflarını ifade etmiştir (2011, s. 9-10). Bireyin, korkakl1k göstermeyip, olacaklardan geri durmayıp yüreklilikle durumların üzerine gitmesini ise "şecaat" olarak izah etmiştir (2011, s. 11). Kınalızade'ye göre, söz konusu fazilet, huy ve davranışlara sahip olan birey, varoluşsal kaygılardan sıyrılabilmekte, kişisel yeterlik düzeylerini üst seviyelere taşıyabilmekte, dünyevi hedefler yerine daha üst ideallere yönelebilmektedir. Böylesi faziletler sayesinde birey; dinine, canına, milletine faydalı olacak ideallere sahip olabilmektedir. $\mathrm{Bu}$ sayede, dünyanın yüksek makam ile aldatıcı olan fayda ve geçici üzüntülerinin etkisinde kalınmamakta, sahip olunan mevki ve makama rıza gösterilmekte, yaraşılmayan yere göz dikilmemektedir (2011, s. 12-13). 
Aubery, Hobbes'un hem dostu hem de yaşam öyküsünü büyük bir ustalıkla hazırlayan yazardır. Aubery, Hobbes'un doğum gününü biraz garip bir şekilde not etmiştir. Zira Hobbes'un doğum günü olan 5 Nisan 1588, İngiltere tarihinde kayıtlı bir gün olma özelliği taşımaktadır. Bu tarihte İspanyol donanmasının İngiltere'ye saldırmak üzere denize açıldığı haberi gelmiştir. Bu haberin İngiltere'de duyulmasıyla, Hobbes'un annesinin doğum sancıları başlamıştır. Hobbes, bu duruma göndermede bulunarak sık sık espri yapmış ve "korku benim ikizimdir, ne de olsa birlikte doğmuştuk" demiştir (Tuck, 2015, s. 14). Bu nedenle Hobbes'un düşüncelerinde, 1srarlı olarak bir güvenlik arayışı yer almaktadır (Zelyüt, 2010, s. 12). Bu arayışı körükleyen bir diğer unsur ise, Hobbes'un gençliğinde revaçta olan Montaigne ile Lipsius'un temsil ettiği anlayıştır. Bu anlayışa göre, tehlikelerle dolu bir dünyada insanların en temel kaygısı kendilerini koruyabilmektir. İşin içine bir de çekişen ideolojiler girdiğinde, durum daha bir tehlikeli hal almaktadır (Tuck, 2015, s. 92). İnsan, Hobbes'a göre, her zaman haz peşinde koşan ve acıdan kaçan 'bencil' bir varlıktır. Bu peşinde koşma ve kaçma duyumlarının temelinde ise bir içgüdü yatar: Kendini koruma ya da yaşamı sürdürme içgüdüsü (Zelyüt, 2010, s. 30).

Hobbes, kişisel güvenlik kaygılarından hareketle; üzeri açık ya da örtülü, kırıcı bir üslup kullanmamak gerektiğini ifade etmiştir. Zira böyle bir üslup, kişinin sevenlerini bile ondan uzaklaştırabildiği gibi, düşmanlarını ve olası çatışmaları, yaşanan çağ itibariyle de düelloları arttırabilmektedir (Furtun, 2005, s. 15). Retorik, etkili ve güzel konuşma yoluyla fikirleri aktarma biçimidir. Bu yönüyle retoriğin, fikirlerin yazıya dökülerek eser yayınlama eylemi ile olan benzerliği, şüphe götürmeyen bir gerçekliktir. Kaldı ki, yazılı belge ortaya koyuyor olması itibariyle, yazı yazma eyleminin, sözsel oluşumdan ibaret olan retorik eyleminden, düşmanlıkları ve olası çatışmaları arttırması çok daha olası görülmektedir. Bu gerçekliğin farkında olan Hobbes, söz konusu olumsuz olasılıkların gündeme gelmemesi için, aklı karışmış okurlara neyi kastettiğini açıklayan ilave yazılar yazmış, bu ise zihinlerdeki soru işaretlerinin tamamını gidermeye yetmemiştir. Kral karşııı bir söylem olabileceği düşünülen hususlarda (dönemin kendine has özellikleri de göz önünde bulundurulduğunda) Herakleitos kadar kapalı söz söyleme sanatına 
başvurmasa da, üstü kapalı sayılabilecek veya farklı anlamlara çekilebilecek açık uçlu politik söylemlere başvurmaktadır. Zira kral veya kralcılar (royalistler) tarafından kendi varlığına yönelik yaşamsal bir tehdidin ortaya çıkmaması için, yanlış anlaşılabilecek politik imalardan kaçınmakla birlikte, kral karşıtlarıyla bağdaştırılabilecek ifadelerden de tümüyle uzak durduğunu ileri sürmek mümkün olmamaktadır. Bu üslubu bilinçli bir tercih olarak benimsemesi de olası gözükmektedir çünkü en çok çekindiği durumların başında, kral yanlısı ve kral karşıtlarının karşı karşıya geldikleri olası bir ülke içi çatışmada, hangi tarafın üstün geleceğine bağlı olarak, yazdığı eserlerde neyi kastettiğini durumsalcı bir şekilde izah edebilme şansına sahip olmak istediği izlenimini uyandırmaktadır. Bu, elbette ki Hobbes'un arzu edebileceği en kötü ihtimaldir çünkü bu riski de ortadan kaldırmak için İngiltere iç savaşında Fransa'ya kaçmıştır.

\section{4. İnsan Doğasına İlişkin Görüşleri}

Kınalızade'ye göre, kendinden yukarı mevkilere göz dikerek, kedere boğulmak, boşuna yorgunluktur. Kınalızade, "akıllı olan kendi derecesinden aşağılara bakarak haline kanaatle şükreder" (2011, s. 26) diyerek rasyonel birey davranışının ne şekilde olması gerektiğini kendi bakış açısına göre açıklamıştır. Kanaatkârlık konusuna vurgu yapan ve bu davranışın faziletlerine ilişkin olarak hadis kökenli deliller sunan Kınalızade; kanaatin, tükenmez bir hazine olduğunu, hırs ve tamahın ise fakirlik getireceğini peygamber efendimizden nakletmiştir. Kınalızade'nin tarif etmiş olduğu birey, günümüzde bütün üniversite ders kitaplarında okutulmakta olan ve neoklasik iktisat öğretisine dayanan, çoğu aza tercih eden, faydasını en çoklamaya, zararını ise en azlamaya çalışan rasyonel insan (rational man, homo economicus) modelinden önemli ölçüde uzak olan, buna karşın Hobbes'un aşağıdaki insan doğasına ilişkin görüşlerine ise daha yakın gözükmektedir.

Hobbes, De Cive adlı kitabının ikinci baskısında, ilk baskıyı okuyanların yorumlarına verdiği cevapla başlamaktadır. Bu cevapta, doğa durumundaki yani sivil bir yönetimin olmadığı bir durumdaki anlaşmazlıkların kaynağını yeniden açıklama ihtiyacı hissetmiştir. Genel algı olarak Hobbes'un, anlaşmazlıkların, bencil insan doğasından kaynaklandığına 
inandığı varsayılmaktadır fakat aşağıdaki aktarımda da görüleceği üzere bu yanıltıcı bir yorumdur (Hobbes, 2014, s. xxvii): Doğa durumu anlatımından, insanlar doğaları gereği kötüdür sonucu çıkmaz. Zira iyiyle kötüyü birbirinden ayıramayacağımızdan, iyilerden daha az sayıda kötü insan olsa bile, dürüst, iyi insanlar mümkün olan her yolla kendilerini korumak için diğerlerini izleme, onlara güvenmeme, tedbirli olma ve diğerlerinden daha güçlü olma ihtiyacı içindedirler.

Farklı şekillerde anlaşılmaya ve yorumlanmaya müsait bu niteliklerinden dolayı, Hobbes'un, insanın doğal yapısına yönelik bakış açısı, bir yönüyle Kant'ın “insanın yapıldığı eğri büğrü odundan, tam doğru bir şey yontulamaz" diyen bakış açısı ile aynı özde işlediği izlenimini uyandırmaktadır. Söz konusu yönüyle Hobbes'u olumsuz bir karakter olarak gören yazarlar olmuştur. Doğulu yazarların Hobbes'u olumsuz karakter olarak görmesini, duygusal bir yaklaşım olarak ifade etmek mümkün olabilmekle birlikte, aynı kanaati taşıyan Batılı yazarların da olduğu görülmektedir. 1870'li y1llarda Hobbes üzerine çalışmalar yapan Ferdinant Tönnies, bunlardan biridir (Tuck, 2015, s. 162).

\section{KINALIZADE VE HOBBES'UN KARŞILAŞTIRILMASINA İLIŞKİN GENEL DEĞERLENDİRME}

Sokrates, yönetim anlayışının evrensel niteliğine işaret eden ilk düşünürdür. Yönetilecek kurum veya kuruluşun farklı yönleri olsa da ortak ve benzer yönlerinin olduğunu vurgulayan Sokrates, ailesini ve özel hayatını iyi yönetemeyen kişilerin devlet ve ordu yönetiminde başarılı olamayacaklarını belirtmiştir. Zira özel işlerin yürütülmesi ile kamu işlerinin yürütülmesi arasındaki tek fark, işin büyüklüğündedir. (Gürüz ve Gürel, 2006, s. 66). Söz konusu evrensel bakış açısından hareket edildiğinde, Kınalızade ile Hobbes arasında var olan ayrımların bulanıklaşması söz konusu olacak, her iki yazar arasındaki farkların belirlendiği çok benzerliklerin ortaya konulduğu bir eşbenzerlik (izomorfizm) tartışması gündeme gelecektir. Buna karşın, başta yönetimsel yapılanmalar olmak üzere, söz konusu yönetimsel yapılanmalara kaynaklık eden her türlü düşünsel arka plan unsurunun, Kınalızade ve Hobbes'un eserlerinde belirgin bir şekilde farklılaşmakta olduğu 
görülmektedir. İlk ve en temel düzey ayrışma olarak iki yazarın Doğu-Batı, idealist-materyalist, normatif-pozitif gibi yol ayrımlarında farklılaşmakta oldukları gözlemlenebilmektedir. Bu ayrışmada her iki yazar da Doğu-Batı anlamında temsil etmiş oldukları dünyayı büyük ölçüde temsil etmektedirler. Zira yaklaşık aynı dönemlerde yaşamış olmalarına karşın, "Nasihat ile kul zapt olunmaz ve iltifat ile düzeltilmesi mümkün değildir. Bu asrın kulu öyle bir kuldur ki... bütün ulema ve şeyhler bir yere gelip bunlara nasihatler eyleyip ögütler verseler... birinin de kulağına girmez ve zerre kadar faydası olmaz. Velhasıl insanoğlu kahır ile zapt olunur; yumuşaklıkla olmaz" diyen Koçi Bey (2008, s. 67) gibi Doğu dünyasının düşünürlerine rastlayabilmek mümkün olabildiği gibi bunun tersi (başta Platon'un kendisi olmak üzere bütün Batılı platonik düşünür ve yazarlar) ile de karşılaşmak mümkün olabilmektedir.

Durkheim, Hobbes'u, sosyologların öncüsü olarak kabul etmiş (2012, s. 23), Tönnies, Kalvanistlerden çok daha önce kapitalist tutumlara ilk ses veren kişi olduğunu ileri sürmüş (Tuck, 20015, s. 166), Curry ve Zarate (1997, s. 148) ile Strauss (2000, s. 8) gibi yazarlar liberalizmin habercisi, Zelyüt (2010, s. 20) ise davranış̧̧ılığın (beheviorism) müjdecisi olarak tanımlamışlardır. Hobbes'u; dini ve ahlaki düşünceleri, yönetimsel yapılanmalardan belirgin ölçülerde soyutlayarak ele almış laik bakış açısının öncüllerinden değerlendirenler de olmuştur (Zarakolu, 2013, s. 54). Hobbes'un kendi kendini ne şekilde tanımladığına bakıldığında ise hiç de alçak gönüllü sayılamayacak bir şekilde şunları söylemektedir: "Politika felsefesi benim De Cive adlı kitabımdan daha eski değildir" (Zelyüt, 2010, s. 29). Hobbes'u bu ve buna benzer çok çeşitli biçimlerde izah eden yazarlar olmuştur. Hobbes'un bu denli çeşitlilik arz eden biçimlerde yorumlanmasının nedeni, farklı ya da yanlış anlaşılmaya müsait olan eklektik tarzından ileri gelmektedir.

$\mathrm{Bu}$ çalışmada, Kınalızade ile Hobbes arasında ikili yol ayrımlarına dayalı mutlak farklılıklar ortaya konulması amaçlanmamaktadır. Zira Kınalızade ile Hobbes'un ortak denilebilecek yönleri de bulunmaktadır. Her iki düşünür de tek tek bireylerin bir araya gelerek devleti oluşturduklarını ifade etmektedirler. $\mathrm{Bu}$ yaklaşım özünde doğru olmakla birlikte, tekil 
bireyden, devlete kadar olan yapılar bakımından bazı kayıp halkaları içinde barındırmaktadır. Tekil bireyden, direkt olarak çok daha üst bir yapılanma düzeyini ifade eden devlet seviyesine geçiş, bazı hiyerarşik basamakların ihmal edilmesine neden olmaktadır. Zira tekil bireyin eylem ve davranışları, ölçek bakımından "mikro" seviyede tezahür etmektedir. Bireyin, örgüt içi gruplarla veya gruplar arasında ortaya çıkan etkileşimin ölçeği ise "meso" seviyeyi ifade etmektedir. Örgütün kendisinin bütün olarak ele alınması doğrultusunda yapılan değerlendirmeler ise ölçek bakımından "makro" seviyeyi işaret etmektedir. Örgütsel yapılanmaların içinde bulunduğu ve örgütler arası etkileşimin ortaya çıktığı düzlem ise "popülasyon" seviyesini açıklamaktadır. Dolayısıyla, tekil birey ile doğrudan doğruya devlet arasında ilişki kuran her türlü indirgemeci yaklaşımda söz konusu kayıp halkalar kendiliğinden ortaya çıkmaktadır. Hobbes'un Leviathan kitabının kapağında yer almakta olan çizimde de bu durum kendini belli etmektedir. Çizimde, devletin başındaki hükümdarın vücudu, yakından incelendiğinde tekil insan figürlerinin bileşiminden meydana gelmekte olduğu görülmektedir. Hobbes'un anlatımlarında birey unsuru vurgulanmakla birlikte, bu bireylerin işbölümü ve uzmanlaşma doğrultusunda belirli bir bütünün oluşmasına katkı sağladığı vurgusu yeterince ele alınmamaktadır. Platon ve Farabi gibi birçok düşünürün vurgulamış olduğu bireylerin işbirliği ve uzmanlaşma davranışı doğrultusunda bütünsel anlamda devleti oluşturan fonksiyonel alt birimlerin müşterek çabası sonucunda güçlü yapıların ortaya çıkacağı vurgusu, Hobbes'un eserlerinde yeterince yankı bulmamıştır.

Yukarıda açıklanan tartışmalara ilave bir boyut getirmesi bakımından şu sorunun sorulması hiç de mantıksız gelmemektedir: "Acaba Hobbes, yönetimsel anlamda izole bir yapılanmayı mı ima etmiştir?" yakın tarihte örneğine rastlanılan "Bağlantısızlar Hareketi" gibi herhangi bir pakta üye olmayan ülkeler makro düzeydeki izole bir yapılanmayı ifade etmektedir. Meso düzeyde, yani örgüt içi gruplar düzeyinde yapılan sosyometrik analizlerde izole bireylerin/kliklerin belirlenebilmesi mümkün olabilmektedir. Mikro düzeyde bakıldığında ise dağ başında münzevi bir şekilde yaşayan bireylerin var olduğu görülmektedir. Analiz düzeyleri bakımından farklılık arz eden makro, meso ve mikro düzeydeki bütün bu izole yapıların, güvenlik 
kaygılarının bir sonucu olarak ortaya çıktıklarını ifade edebilmek, Hobbes bakış açısından hiç de yanıltıcı görünmemektedir. Zira Hobbes'a göre birey, belirli bir neden olmasa bile başkaları tarafından beklenmedik bir şekilde canına, varlığına yönelik bir saldırıya uğrayacağını yönündeki varoluşsal kayg1 içinde yaşamaktadır. Söz konusu paranoya düzeyindeki güvenlik kaygısı, uluslararası ilişkiler alanına da yansımış realist düşünür ve yazarları fazlasıyla etkilemiş, hatta ülkelerin güvenlik politikalarının şekillenmesi bakımından da kendine özgü bir anlayış biçimine dönüşmüştür. İşte tam da bu nedenle, söz konusu anlayış, uluslararası ilişkilerde izolasyon politikalarıyla bağdaştırılabilecek hususları çağrıştırmaktadır.

Bireyden direkt olarak devletin oluşması anlayışını, en iyimser yorumla organizmacı anlayışın benimsenmesi olarak değerlendirebilmek mümkün gözükmektedir çünkü Hobbes'un bu indirgemeci anlayışından çok daha kapsamlısına çok daha erken dönem düşüncelerde, örneğin onuncu yüzyıl filozofu Farabi'de de rastlanmaktadır. Farabi'ye göre, uyumlu organlar bütünü olarak devlet organizmasının, her organı, belirli bir işleve sahip bulunmaktadır fakat bu işlevlerin bir kısmı birincil, diğerleri ise ikincil ve üçüncül derecede önemlidir. Organizmanın en önemli organları üst bölümde yer almaktadır. Aşağı doğru gidildikçe önem derecesi düşmektedir. Toplumlarda da benzer şekilde üstte yönetici kesimler altta ise bunların buyruklarını yerine getirerek hizmet üreten insanlardan oluşmaktadır (Aydın, 2004, s. 123). İnsanların salt fiziksel varlıklar olduğuna inanan bir materyalist olarak Hobbes'un organizma tasavvuru, bu görüşten belirli ölçülerde farklılık gösteriyordu. Hobbes, insanı karmaşık makineler olan bedenlerden başka bir şey olarak görmüyordu. Zira bu yüzyıllarda saat mekanizmaları en ileri teknolojiydi. Hobbes, bedendeki kasların ve organların bunlara eşdeğer olduğuna inanıyordu (Warbuton, 2017, s. 97). Determinizmden çok etkilenen Hobbes, bu inancı çok daha ileriye taşıyarak sivil toplumun bütününün de onu oluşturan ve mekanik olarak belirlenmiş bireyler tarafindan yine mekanik bir düzen doğrultusunda belirlendiğini düşünüyordu (Hobbes, 2017, s. 17; Osborne, 1996, s. 55) fakat Hobbes'in yaklaşımı daha atomist bir düzeyde kalıyordu ve örneğin öncülü düşünürleri olan Farabi'nin yaptığı gibi işlevselciği kapsamlı bir şekilde açıklayarak işbölümü ve uzmanlaşmayı 
vurgulamak yerine, yani yönetimsel yapılanmaların (örneğin devletin) bütünselliğine işlevselci yaklaşmamakta, insan yığını (bunch of human) gibi ele almaktadır. Devletlerin kaderini belirleyen nedenleri bilebilirsek, onların kaderine hükmedebiliriz (Zelyüt, 2010, s. 17) diyen Hobbes, analitik-sentetik yani ayırma-birleştirme yöntemi sayesinde tıpkı saatin parçalarından hareket ederek bütününün yapılandırılabileceği ve hem parça hem de bütün hakkında mutlak belirlemeciliğe (determinizme) ulaşılabileceğini düşünmektedir. Durkheim (2012, s. 28) ise "böylesi bir mekanik yap1 pek de akıl kâr1 görünmüyor, hatta Locke'dan itibaren zayıf çözümlemelere saplanıp kalmış İngiliz felsefesine bir hayli benziyor" diyerek Hobbes'u eleştirmiştir.

\section{SONUÇ}

$\mathrm{Bu}$ çalışmada, genel anlamda Kınalızade ile Hobbes'un yönetim yaklaşımları arasındaki ayrımlar üzerinde durulmuştur. Buna karşın, iki filozof arasında sınırlı bazı konularda ortaya çıkan benzer hususlara da değinilmiştir. "Yönetim yaklaşımı" kavramı, çok farklı alanları içine alan kapsamlı bir alanı ifade edebilmektedir. Dolayısıyla, söz konusu kapsamın daraltılarak, bu makaledeki gibi mikroanalitik bir çalışmanın yürütülebileceği ölçülerde konunun daraltılması gereği ortaya çıkmıştır. Bu gerekliliği yerine getirebilmek için makalede öncelikle Kınalızade ile Hobbes'un yöneticiyönetilen ilişkilerine dair görüşleri üzerinde durulmuş, bağımlılık ilişkisinin tek yanlı veya karşılıklı bağımlılık biçiminde algılanması ve benzer türden değerlendirmeler yapılmıştır. Düşünürlerin, güç ve hakimiyet ilişkisine bakış açıları da bu yaklaşık aynı eksende izah edilmiştir. Bireylerin varoluşsal kaygılarına dair görüşleri ise düşünürlerin geçmiş yaşantıları doğrultusunda değerlendirilmiştir. Zira "geçmiş yaşantılar, bireyin kişiliğinin oluşumunda önemli bir yer işgal etmektedir" (Adler, 2011, s. 101). Bu anlayışa göre, düşünür ve yazarların geçmiş yaşantıları, yazma tarzları bakımından belirleyici bir husus olarak ortaya çıkmaktadır. Hobbes'un geçmiş yaşantılarının (özellikle çocukluk dönemine yansımış olan varoluşsal korkularının), yazılarına olan etkisi çok belirgin bir nitelik taşımaktadır. Buna karşın, Kınalızade'nin geçmiş yaşantıları ile yazdığı eserleri arasında korelasyon gözetmek oldukça zor bir husus olarak belirginlik göstermektedir. Karşılaştırma içeren anlatımlarda son olarak düşünürlerin, insan doğasına 
ilişkin görüşlerine yer verilmiştir. İnsanın doğasına ilişkin her türlü tasavvur, onun davranışlarını açıklayıcı mekanizmaları da beraberinde getirmektedir. Kınalızade ve Hobbes, kendi kişisel çıkarımları ve tasavvurları doğrultusunda insan doğasını açıklamış, söz konusu insan doğasının, davranışlara ne şekilde yansımakta olduğunu izah etmişlerdir.

$\mathrm{Bu}$ makalede, Kınalızade ile Hobbes'un görüşlerinin ardışık olarak sıralanması ile yetinilmemiş, ele alınan görüşlere ilişkin ikincil kaynak eserlerdeki görüşlere de yer verilmiş, ilave değerlendirmeler de yapılmıştır. İki düşünürün karşılaştırılması, salt metinlerin kıyaslanması veya analizine dayalı olarak yürütülmemiş, genel anlamdaki değerlendirmelere de yer verecek biçimde gerçekleştirilmiştir. Bu yönüyle çalışma, bu alanda yapılacak daha kapsamlı ve farklı boyutları da ele alan çalışmalara davet niteliği taşımaktadır.

\section{KAYNAKLAR}

Adler, A. (2011a). Yaşama Sanatı, 11. Baskı, Çev. Kâmuran Şipal, İstanbul: Say Yayınları.

Arıboğan, D. Ü. (1998). Kabileden Küreselleşmeye Uluslararası İlişsiler Düşüncesi. İstanbul: Sarmal.

Atayman, V. (2006). Hukuk Felsefesi. İstanbul: Don Kişot Güncel Yayınlar. Aydın, A. (2004). Düşünce Tarihi ve İnsan Doğası. İstanbul: Gendaş Kültür. Curry P. \& Zarate, O (1997). Machiavelli. Çev. Mehmet Harmancı, İstanbul: Milliyet Yayınları.

Cıvgın, İ. \& Yardımcı R. (2007). Siyasal Düşünceler Tarihi, Ankara: Nobel. Copelston, F. (1998). Felsefe Tarihi, Çev. Aziz Yardımlı, İstanbul: İdea. Davutoğlu, A. (2010). Stratejik Derinlik. İstanbul: Küre.

Gürüz, D. \& Emet G. (2006). Yönetim ve Organizasyon. Ankara: Nobel. Hobbes, T. (2014). Elemanta Philosohica De Cive Yurttaşlık Felsefesinin Temelleri. Çev. Cihan Denzi Zarakolu, İstanbul: Belge.

Hobbes, T. (2017). Leviathan. Çev. Semih Lim, İstanbul: Yapı Kredi.

Fukuyama, F. ve diğ. (Der. Mustafa Aydın, Ertan Özensel) (2003). Tarihin Sonu mu?. Davutoğlu, Ahmet, "11 Eylül Sonrasının Tarihi Üzerine, Ahmet Demirhan'ın Mülakatı”, Ankara: Vadi. 
Fukuyama, F. (2005). Devlet İnşası 21. Yüzyılda Dünya Düzeni ve Yönetişim.

Çev. Devrim Çetinkasap, Remzi Kitabevi, İstanbul, 62

Keskin, U. (2012a). Batı Dünyasındaki Prens İçin Ayna ve Doğu Dünyasındaki Hükümdar İçin Nasihatnamelerin İncelenmesi, EKEV Akademi Dergisi, S: 52, ss. 151-178.

Keskin, U. (2012b). Yönetim Felsefesi. İstanbul: Değişim.

Keskin, U. \& Büyük K. (2013). Stratejik Performans Yönetimi. 2. Bask1, İstanbul: Akis Kitap.

Kınalızade Ali Efendi, (2010). Devlet ve Aile Ahlakn. İstanbul: İlgi Kültür Sanat.

Kınalızade Ali Efendi, (2011). Ruhun Üç Kuvveti. İstanbul: Hayat.

Koçi Bey, (2008). Koçi Bey Risaleleri. İstanbul: Kabalc1.

Osborne, R. (1996). Herkes İçin Felsefe. Çev. M. Doğan Şahiner, İstanbul: Milliyet.

Öztürk, H. (1991). Kınalızade Ali Çelebi'de Aile Ahlakı. Ankara: T.C. Başbakanlık Aile Araştırma Kurumu Başkanlığı.

Özdemir, R. (2012). Zaman ve Mekân Bağlamında Karşılaştırmalı Bir Çalışma: Makyavel'in "Prens"i ve Kınalızade'nin Ahlâk-i Alâi'si. Turkish Studies, Vol 7/3, Ankara, ss. 1993-2011.

Saruhan, Ş.C. \& Özdemirci, A. (2005). Bilim, Felsefe ve Metodoloji. İstanbul: Alkım.

Strauss, L. (2000). Politika Felsefesi Nedir?. Çev. Solmaz Zeylüt Hünler, İstanbul: Paradigma.

Tuck, R. (2015). Hobbes, Ankara: Dost Kitabevi.

Ülken, Z. H. (2009). Uyanış Devirlerinde Tercümenin Rolü. İstanbul: İş Bankas1 Kültür.

Yavuz, E. (2015). On Altıncı Yüzyll Doğu ve Batı Düşünürlerinde Yönetim Düşüncesi ve Karşılaştırmalı Analizi. (Yayınlanmış yüksek lisans tezi) Eskişehir Osmangazi Üniversitesi Sosyal Bilimler Enstitüsü, Eskişehir, Türkiye.

Warbuton, N. 2017, Felsefenin Kısa Tarihi. Çev. Güçlü Ateşoğlu, İstanbul: Alfa. 
Watkins, J.W.N. (2000), Thomas Hobbes. (Ed. Maurice Cranston), Bat1 Düşüncesinde Siyaset Felsefeleri içinde Çev. Nejat Muallimoğlu, (ss. 53-62), İstanbul: Marmara Üniversitesi İlahiyat Fakültesi.

Zarakolu, C. D. (2013). Thomas Hobbes'un Siyaset Felsefesi. İstanbul: Belge. Zelyüt, S. (2010). Dört Adalı Hobbes Locke Berkeley Hume. Ankara: Doğu Batı. 